\title{
PENGEMBANGAN PERANGKAT PEMBELAJARAN FISIKA BERBASIS MASALAH UNTUK MENINGKATKAN HASIL BELAJAR DAN SIKAP ILMIAH MAHASISWA
}

\author{
I Wayan Gunada, Hairunnisyah Sahidu, Sutrio \\ Program Studi Pendidikan Fisika \\ Universitas Mataram \\ Mataram, Indonesia \\ Email : wayan_gunada@yahoo.com
}

\begin{abstract}
This study aims to develop problem-based learning device in terms of validity and student responses. Learning device was developed covering the syllabus, lesson plans, fundamental of physics textbook, exsperiment in fundamental physics, worksheets, and learning outcome test. The expected benefits of this research is the problem-based learning tools that can be used as an alternative to the lecturer of the fundamental of physics learning in FKIP Mataram of University.This refers to the process of developing 4D models (define, design, develop, disseminate). The results validate the lecturer learning device consisting of a syllabus, lesson plans, fundamental of physics textbook, experiment in fundamental physics, worksheets, and learning outcome test successivelyobtained scores of 2.65, 2.68, 3.30, 3.25, 2.285 and 3.14 are decent categorized. Student learning outcomes is seen from indicators of student achievement of cognitive learning and experiment processes value row gets a percentage of $76.80 \%$ and $78.50 \%$, while the scientific attitude students which amounted average value of 76.42 and scientific attitude students can be interpreted good categorized. The positive student responses which amounted to $85.90 \%$. From the validation results, student learning outcomes and student responses can be interpreted decent device.
\end{abstract}

Keywords: problem-based learning, scientific attitude.

\section{Pendahuluan}

Fisika adalah bidang Ilmu Pengetahuan Alam yang menyediakan pengalaman untuk memahami konsep dan kemampuan memecahkan masalah. Materi perkuliahan fisika diperoleh dalam mata kuliah fisika dasar. Mata kuliah fisika dasar merupakan mata kuliah yang wajib di tempuh oleh mahasiswa PS. Pendidikan Matematika, PS. Pendidikan Kimia, PS. Pendidikan Biologi, maupun PS. Pendidikan Matematika Reguler Sore di lingkungan Pendidikan MIPA FKIP Universitas Mataram.

Penyajian mata kuliah fisika dasar terintegrasi antara teori dan praktik, dalam hal ini kemampuan dan hasil belajar mahasiswa ditentukan secara utuh meliputi ranah kognitif, afektif, dan psikomotor. Tercapainya kualitas perkuliahan yang baik apabila tersedia perangkat pembelajaran yang baik pula. Menurut [1] menyatakan bahwa peningkatan kualitas pembelajaran seorang dosen sangatlah strategis, karena ia berfungsi sebagai ujung tombak terjadinya perubahan (the agent of change) dari belum bisa menjadi bisa, dari belum menguasai menjadi menguasai, dari belum mengerti menjadi mengerti, melalui proses pembelajaran. Selain itu, [2]mengatakan bahwa faktor mahasiswa, sarana, alat dan media yang tersedia, serta faktor lingkungan, juga dapat mempengaruhi proses pembelajaran.

Kenyataannya yang terjadi di lapangan terkait dengan proses perkuliahan fisika dasar, bahwa perkuliahan fisika dasar belum berjalan secara optimal dan belum menunjukkan peningkatan hasil belajar mahasiswa, hal ini dapat dilihat dari kesulitan belajar yang dialami mahasiswa dalam kegiatan memperhatikan dan mendengarkan penjelasan dosen, bertanya atau menyatakan pendapat, melakukan pengamatan, diskusi, serta mengerjakan LKM, yang disebabkan karena kurangnya kesiapan mahasiswa dalam mengikuti perkuliahan, kurangnya peran serta mahasiswa dalam proses pembelajaran serta kurangnya penguasaan materi.

Hal lain yang dijumpai berdasarkan pengamatan yang dilakukan oleh peneliti, terkait dengan perkuliahan fisika dasar yang selama ini berlangsung diperoleh bahwa, pada saat perkuliahan berlangsung terlihat mahasiswa tidak bisa menemukan sendiri konsep fisika untuk memecahkan masalah, selain itu mahasiswa menjadi kurang teliti dalam pelaksanaan praktikum, data yang diperoleh bukan berdasarkan hasil pengamatan sendiri melainkan mencontoh data yang diperoleh dari kelompok lainnya, serta rendahnya rasa tanggung jawab mahasiswa terhadap kegiatan pembelajaran yang dilakukan.

Sikap mahasiswa di atas seperti : rasa ingin tahu, kurang teliti, kurang percaya diri, tidak jujur merupakan cerminan rendahnya sikap ilmiah mahasiswa. Menurut [3] rendahnya sikap ilmiah mahasiswa terhadap pembelajaran fisika dikarenakan proses pembelajaran yang diterapkan selama ini masih 
menggunakan metode ceramah yang divariasi dengan diskusi, selain itu rendahnya tingkat kemampuan bertanya guru/dosen yang mampu membangkitkan motivasi bagi mahasiswa untuk mengikuti proses pembelajaran. Seperti yang diungkapkan [4] bahwa upaya meningkatkan kemampuan mahasiswa tidak hanya dalam aspek kognitif tetapi yang terpenting juga adalah kemampuan sikap ilmiah mahasiswa untuk membentuk karakter yang berpengetahuan ilmiah.

Melihat kenyataan tersebut diperlukan pengembangan perangkat pembelajaran dengan mengimplementasikan model pembelajaran berbasis masalah yang merupakan upaya untuk meningkatkan mutu pendidikan. Karena bentuk nyata dari persiapan dosen adalah membuat perangkat pembelajaran sebelum melaksanakan kegiatan perkuliahan. Perangkat pembelajaran nantinya dapat digunakan sebagai pedoman dosen untuk mencapai tujuan pembelajaran yaitu meningkatnya hasil belajar dan sikap ilmiah mahasiswa.

Pengembangan perangkat pembelajaran dengan mengimplementasikan model pembelajaran yang berorientasi pada pembelajaran berbasis masalah didasarkan pada karakteristik dari model pembelajaran yang menghadapkan mahasiswa pada masalah nyata, kemudian mahasiswa dapat memecahkannya melalui kegiatan ilmiah salah satunya melalui penyelidikan lewat praktikum. Masalah nyata yang dihadapkan pada mahasiswa dalam model pembelajaran berbasis masalah akan menimbulkan ketertarikan dan rasa ingin tahu yang besar pada pebelajar. Hal ini diperkuat dengan penelitian yang telah dilakukan [5] yang menyatakan bahwa model pembelajaran berbasis masalah efektif digunakan untuk meningkatkan sikap ilmiah siswa dan diperkuat dengan hasil penelitian yang dilakukan [3], menyatakan bahwa sikap ilmiah hasil siswa yang belajar menggunakan model pembelajaran berbasis masalah lebih baik daripada siswa yang belajar dengan model ekspositori. Pembelajaran berbasis masalah juga mempersiapkan peserta didik menjadi orang mandiri. Peserta didik dihadapkan pada masalah aktual, mereka belajar memecahkan masalah seperti yang mereka perlukan pada saat mereka berada dimasyarakat [6].

\section{Tinjauan Pustaka}

\section{A. Pengembangan Perangkat Pembelajaran}

Pengembangan perangkat pembelajaran merupakan proses atau kegiatan yang dilakukan untuk menghasilkan suatu perangkat pembelajaran berdasarkan teori pengembangan. Sedangkan perangkat pembelajaran merupakan segala alat dan bahan yang digunakan guru untuk melakukan proses pembelajaran. Bahan ajar adalah segala bentuk bahan yang digunakan untuk membantu guru dalam melaksanakan kegiatan pembelajaran. Bahan yang dimaksud dapat berupa bahan tertulis. Menurut Keputusan Menteri Pendidikan Nasional Nomor:36/D/0/2001 yang dimaksud dengan pengembangan bahan pengajaran adalah hasil pengembangan inovatif materi substansial pengajaran dalam bentuk buku ajar, diktat, modul, petunjuk praktikum, model, alat bantu, audio visual, naskah tutorial. Perangkat pembelajaran yang dikembangkan meliputi : Silabus, RPP, Buku Ajar Fisika Dasar, Buku Petunjuk Praktikum, Lembar Kerja Mahasiswa (LKM), dan Tes Hasil Belajar Mahasiswa. Buku ajar dan petunjuk praktikum yang dimaksud di atas adalah berdasarkan Keputusan Menteri Pendidikan Nasional Nomor:36/D/0/2001 Pasal 5 ayat 9a dan 9c yang menyatakan bahwa buku ajar adalah buku pegangan untuk suatu matakuliah yang ditulis dan disusun oleh pakar bidang terkait dan memenuhi kaidah buku teks serta diterbitkan secara resmi dan disebarluaskan. Sedangkan petunjuk praktikum adalah pedoman pelaksanaan praktikum yang berisi tata cara persiapan, pelaksanaan, analisis data dan pelaporan. Pedoman tersebut disusun dan ditulis oleh kelompok staf pengajar yang menangani praktikum tersebut dan mengikuti kaidah tulisan ilmiah.

\section{B. Pembelajaran Berbasis Masalah}

Model pembelajaran berbasis masalah (problem based learning) sering disingkat dengan PBM. Menurut Krisanti dan Mulia, 2004 dalam [7] menyatakan bahwa pada dasarnya pembelajaran berbasis masalah (problem based learning) merupakan metode instruksional yang menantang mahasiswa agar belajar untuk belajar, bekerja sama dalam kelompok untuk mencari solusi bagi masalah yang nyata. Sedangkan [8] menyatakan bahwa model pembelajaran berbasis masalah merupakan suatu model pembelajaran yang didasarkan pada banyaknya permasalahan yang membutuhkan penyelidikan autentik yakni penyelidikan yang membutuhkan penyelesaian nyata dari permasalahan yang nyata. [9] menambahkan bahwa karakteristik masalah yang ingin dipecahkan adalah masalah nyata yang berkaitan dengan upaya novatif atau penerapan teknologi dalam pembelajaran sebagai pertanggungjawaban profesional dan komitmennya terhadap pemerolehan kualitas pembelajaran.

Adapun menurut [10], pembelajaran berbasis masalah adalah model pembelajaran yang berlandaskan konstruktivisme dan mengakomodasikan keterlibatan siswa dalam belajar serta terlibat dalam pemecahan masalah yang kontekstual. Hal ini menunjukkan pembelajaran berbasis masalah selalu melibatkan siswa dalam penyelesaian masalah dan masalah yang digunakan adalah masalah nyata yang sering siswa temukan 
bahkan siswa alami sendiri dalam kehidupan seharihari.

Menurut Arends (2009) yang dikutip dalam bahwa [10] terdapat 5 sintaks dari pembelajaran berbasis masalah secara umum yaitu: (1) orientasi masalah kepada siswa; (2) mengorganisasikan siswa untuk belajar; (3) membimbing penyelidikan atau individual; (4) mengembangkan dan menyajikan hasil karya; (5) menganalisis dan mengevaluasi proses pemecahan masalah.

\section{Hasil Belajar}

Seperti yang diungkapkan [11] mengemukakan bahwa hasil belajar merupakan suatu perubahan yang dicapai oleh seseorang setelah mengalami proses belajar. Perubahan itu meliputi tingkah laku secara menyeluruh dalam sikap, keterampilan, dan pengetahuan. Sedangkan, menyatakan bahwa hasil belajar adalah perwujudan kemampuan akibat perubahan perilaku yang dilakukan oleh usaha pendidikan. Kemampuan menyangkut domain kognitif, apektif, dan psikomotorik. Hasil belajar adalah bila seseorang telah belajar akan terjadi perubahan tingkah laku pada orang tersebut, misalnya dari tidak tahu menjadi tahu, dan dari tidak mengerti menjadi mengerti. Hasil belajar merupakan ukuran kuantitatif yang mewakili kemampuan yang dimiliki oleh siswa. Untuk itu hasil belajar harus diidentifikasi bidang studi yang hendak diukur hasil belajarnya. Menurut [12], hasil belajar adalah pola-pola perbuatan, nilai-nilai, pengertian-pengertian, sikap-sikap, apresiasi dan keterampilan.

Berdasarkan uraian di atas, dapat disimpulkan bahwa hasil belajar adalah perubahan kemampuan yang diperoleh setelah pelaksanaan kegiatan pembelajaran. Hasil belajar yang dimaksud adalah hasil belajar kognitif yaitu perubahan kemampuan intelektual yang diperoleh siswa setelah memperoleh perlakuan model Pembelajaran Berbasis Masalah dalam kegiatan pembelajaran. Hal tersebut juga menunjukkan bahwa hasil belajar tidak terjadi secara tiba-tiba, melainkan memerlukan usaha yang dalam hal ini adalah perlakuan dalam kegiatan pembelajaran.

\section{Sikap Ilmiah}

Sikap ilmiah merupakan sikap yang harus ada pada diri seorang ilmuwan atau akademisi ketika menghadapi persoalan-persoalan ilmiah. Menurut Harlen dalam [5] indikator sikap ilmiah yang diteliti : rasa ingin tahu, respek terhadap fakta atau bukti, kemauan untuk mengubah pandangan, dan berpikir kritis .

\section{Metode Penelitian}

Penelitian ini merupakan penelitian pengembangan (Developmental Research). Pengembangan perangkat pembelajaran fisika berorientasi pada pembelajaran berbasis masalah (PBM) untuk meningkatkan hasil belajar dan sikap ilmiah mahasiswa.

Model pengembangan yang digunakan dalam mengembangkan perangkat pembelajaran berorientasi pembelajaran berbasis masalah mengacu pada model pengembangan [13] yang dikenal dengan istilah 4-D. Model 4-D ini terdiri dari 4 tahap yaitu : tahap pendefinisian (Define), perancangan (Design), pengembangan (Develop), dan penyebaran (Disseminate). Penelitian ini dilaksanakan pada semester gasal tahun ajaran 2013/2014 di Jurusan Pendidikan MIPA FKIP Unram. Sasaran penelitian ini perangkat pembelajaran fisika berorentasi pembelajaran berbasis masalah untuk mahasiswa yang menempuh mata kuliah fisika dasar layanan di FKIP Unram yang terdiri dari Silabus, RPP, Buku Ajar Fisika Dasar, Buku Petunjuk Praktikum, Lembar Kerja Mahasiswa (LKM), dan Tes Hasil Belajar Mahasiswa. Populasi penelitian adalah mahasiswa yang menempuh mata kuliah fisika dasar layanan semester gasal 2013/2014, sedangkan sampel penelitian adalah mahasiswa PS. Pendidikan Matematika Reguler Sore yang menempuh mata kuliah fisika dasar. Metode pengumpulan data dilakukan dengan metode angket telaah, metode angket validasi, metode angket respon mahasiswa, dan hasil belajar mahasiswa. Metode analisis data yang digunakan adalah analisis validasi pakar, analisis angket respon mahasiswa, analisis hasil belajar, dan sikap ilmiah mahasiswa.

Untuk buku ajar fisika dasar ada 14 aspek yang dinilai meliputi : 1) ketepatan judul bab dengan isi materi buku ajar dalam setiap bab, 2) kejelasan kerangka isi, 3)kesesuaian antara kompetensi dasar dan indikator hasil belajar, 4) kesesuaian materi perkuliahan dengan tujuan perkuliahan , 5) kejelasan uraian materi, 6) kriteria yang dapat digunakan sebagai indikator penilaian sesuai dengan tujuan perkuliahan, 7) kejelasan dan kebenaran konsepkonsep tiap bab, 8) ketersediaan gambar menunjang materi buku ajar, 9) kejelasan contoh - contoh yang diberikan di sertai dengan strategi pemecahan masalah, 10) kesesuaian antara latihan soal dengan indikator hasil belajar, 11) keterbacaan bahasa, 12) tata bahasa menggunakan kaidah bahasa baku dan menggunakan bahasa ilmiah, 13) konsistensi dalam penggunaan gaya penulisan yang dipakai dalam menyusun buku ajar, 14) literatur yang digunakan dalam penyusunan buku ajar relevan dengan materi yang disajikan.

Sedangkan untuk buku petunjuk praktikum ada 10 aspek yang dinilai meliputi: 1)kesesuaian petunjuk praktikum dengan materi perkuliahan, 2) desain judul satuan praktikum, 3) sistematika petunjuk praktikum, 4)kejelasan tujuan praktikum, 5) kejelasan dasar teori, 6) kejelasan prosedure pelaksanaan praktikum, Manfaat dasar teori dalam mendukung 
pelaksanaan praktikum Manfaat dasar teori dalam mendukung pelaksanaan praktikum Kesesuaian warna, tulisan, dan tulisan dalam petunjuk praktikum Kebakuan bahasa yang digunakan dan kemudahan responden dalam memahami bahasa

\section{Hasil dan Pembahasan}

Pada penelitian ini telah berhasil mengembangkan perangkat pembelajaran fisika yang beroreintasi pada pembelajaran berbasis masalah dengan tahapan pengembangannya dengan model 4-D.

\section{Tahap Pendefinisian (Define)}

Pada tahap pendefinisian dilakukan analisis. Adapun tujuan dari tahapan ini adalah menetapkan dan mendefinisikan syarat pembelajaran yang diawali dengan analisis tujuan dan kebutuhan. Teknik yang digunakan dengan melakukan pendokumentasian dan wawancara untuk mengetahui pentingnya pengembangan perangkat pembelajaran berbasis masalah. Kegiatan yang dilakukan pada tahap ini mencakup hal-hal sebagai berikut : a) menganalisis kurikulum terkait dengan pembelajaran fisika dasar layanan di lingkungan FKIP Unram dan diperoleh bahwa mata kuliah fisika dasar berbobot 4 SKS (teori dan praktikum). Sehingga kompetensi yang diharapkan, yaitu mahasiswa mampu memecahkan permasalahan dengan analisis konsep maupun praktikum; b) menganalisis perangkat pembelajaran yang sebelumnya digunakan untuk perkuliahan. Berdasarkan dari beberapa dokumen diperoleh, bahwa belum adanya buku ajar fisika dasar yang representatif dan tidak ada tahapan melakukan suatu analisis pemecahan masalah. Padahal melakukan analisis data sangatlah penting dalam kegiatan perkuliahan, buku petunjuk praktikum kurang memadai; c) berdasarkan beberapa input dari dosen pengampu mata kuliah fisika dasar layanan menyatakan bahwa kegiatan perkuliahan monoton, dosen tidak mempunyai pedoman yang sama dalam mengajar, praktikum belum berjalan maksimal karena beberapa faktor, diantaranya buku petunjuk belum memadai; d) sedangkan analisis mahasiswa diperoleh berdasarkan perkembangan kognitif mahasiwa. Kemampuan mahasiswa ini dijadikan dasar dalam peerancangan Lembar Kerja Mahasiswa (LKM). Hal lain yang diperoleh dari kegiatan praktikum mahasiswa antara lain , kesungguhan mahasiswa dalam praktikum belum optimal, rasa ingin tahu dan kejujuran dalam melaporkan data hasil praktikum masih kurang. Hal ini menunjukan bahwa sikap mahasiswa tersebut bertentangan dengan sikap ilmiah mahasiswa. Karena pada dasarnya sikap yang harus dikembangkan oleh seorang mahasiswa adalah sikap ilmiah, yang indikatornya yang terdiri dari: rasa ingin tahu, respek terhadap fakta atau bukti, kemauan untuk mengubah pandangan, dan berpikir kritis. Berdasarkan data awal dan analisis mahasiswa tersebut dikembangkan perangkat pembelajaran fisika berbasis masalah. Mahasiswa yang belajar dimulai dari pemberian masalah real, maka mahasiswa akan terbiasa untuk memecahkan masalah. Hal ini akan membiasakan mahasiswa untuk berpikir secara terstruktur, dan menemukan sendiri konsep-konsep yang akan dipelajari. Pemecahan masalah yang dilakukan pada model pembelajaran berbasis masalah, dapat mengembangkan kemampuan berpikir tingkat tinggi dan berpikir kritis yang pada akhirnya mengarahkan siswa untuk dapat mencapai hasil belajar yang lebih baik dan meningkatkan sikap ilmiah mahasiswa.

\section{Tahap Perencanaan (Design)}

Tahap perencanaan produk awal yang dikembangkan dirancang perangkap pembelajaran berbasis masalah yang terdiri dari : silabus, RPP, Buku Ajar, Petunjuk Praktikum, dan LKM beorientasi pada pembelajaran berbasis masalah. Secara detail produk desain pengembangan perangkat pembelajaran yaitu: silabus dan RPP dapat dilihat pada gambar 1 .

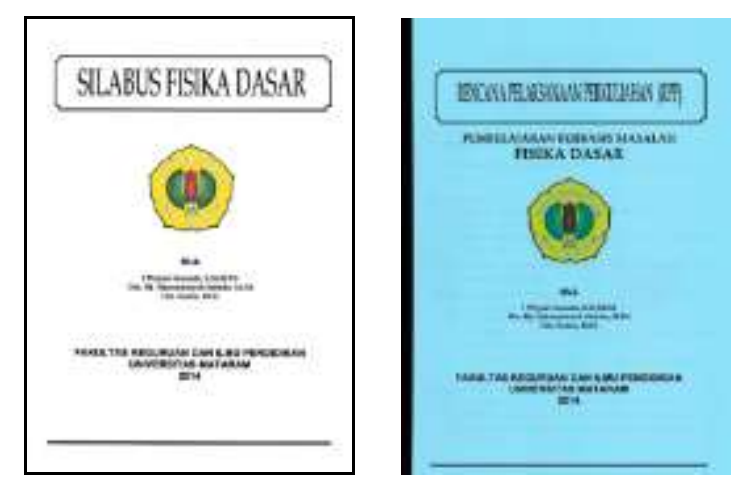

Gambar 1. Silabus dan RPP Hasil Pengembangan.

Silabus mata kuliah fisika dasar layanan dirancang sesuai dengan kebutuhan di Jurusan Pendidikan MIPA FKIP Unram dan RPP dirancang dengan desain model pembelajaran berbasis masalah.
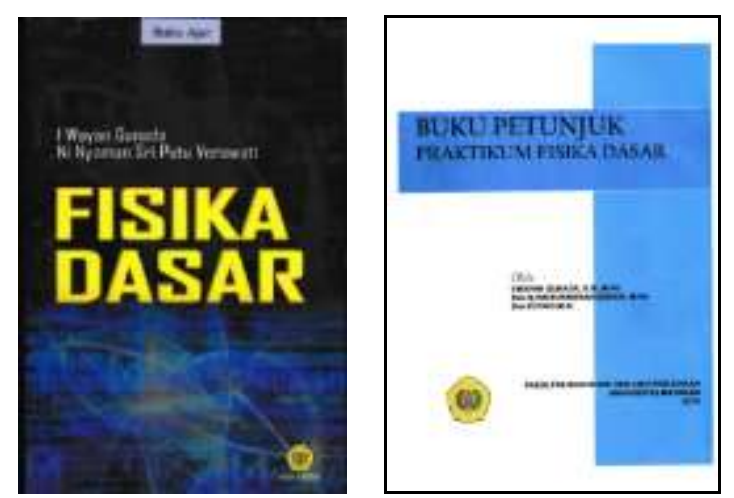

Gambar 2. Gambar Buku Ajar Fisika Dasar dan Buku Petunjuk Praktikum

Secara garis besar buku ajar fisika dasar hasil pengembangan berisikan: sampul muka, kata pengantar, tinjauan mata kuliah, deskripsi mata kuliah, petunjuk penggunaan buku ajar, capaian pembelajaran 
mata kuliah, kemampuan akhir yang diharapkan, daptar isi, uraian tiap bab, daftar pustaka. Sedangkan tiap-tiap bab berisikan : judul bab,standar kompetensi, kompetensi dasar, indikator, uraian materi, contoh permasalahan berbasis masalah, rangkuman, dan latihan soal. Buku ajar fisika dasar dirancang dalam 10 bab yang terdiri dari materi : Bab I Besaran dan Pengukuran, Bab II Vektor, Bab III Kinematika Partikel dalam Satu Dimensi, Bab IV Kinematika Partikel dalam Dua Dimensi, Bab V Dinamika Partikel, Bab VI Usaha dan Energi, Bab VII Momentum Linier, Bab VIII Elastisitas dan Gaya Pegas, Bab IX Suhu dan Kalor dan Bab X Termodinamika.

Untuk buku petunjuk praktikum fisika dasar berisi tentang : cover, kata pengantar, daftar isi, tata tertib praktikum, satuan praktikum, daftar pustaka dan lampiran yang beriri tentang tata cara pembuatan laporan dan perhitungan rata pengukuran. Satuan praktikumnya terdiri dari : Percobaan I Pengukuran Mekanik dan Ketidakpastian, Percobaan II Hukum Newton, Percobaan III Bandul Sederhana, Percobaan IV Gerak Lurus beraturan, Percobaan V Elastisitas, Percobaan VI Kalor, dan PercobaanVII Pengukuran Laju Aliran Kalor pada.
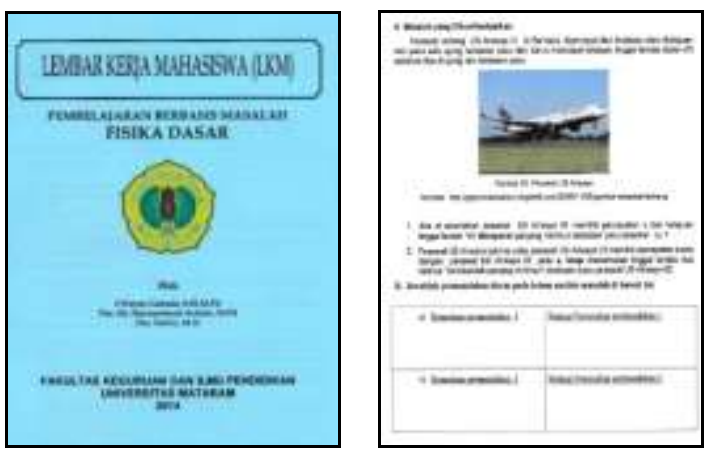

Gambar 3. Gambar LKM dan Contoh LKM

Berorientasi Pembelajaran Berbasis Masalah Pada Bahasan Kinematika

Lembar Kerja Mahasiswa (LKM) yang dikembangkan terdiri dari 6 LKM yaitu LKM Besaran dan Pengukuran, LKM Kinematika Partikel, LKM Suhu dan Kalor, LKM Momentum dan Impuls, LKM Suhu dan Termometer, dan LKM Usaha dan Energi. Struktur LKM yang dikembangkan terdiri dari : judul, petunjuk LKM, kompetensi yang dicapai, informasi /wacara berorientasi pembelajaran berbasis masalah, langkah-langkah kerja dan penilaian.

\section{Tahap Pengembangan (Develop)}

Pada tahap ini, bertujuan untuk menghasilkan perangkat pembelajaran berbasis masalah pada mata kuliah fisika dasar. Telaah dilakukan oleh dosen ahli PS. Pendidikan Fisika FKIP Unram. Hasil yang diperoleh adalah kritik dan saran yang kemudian direvisi/diperbaiki sehingga didapatkan draft 2 yang kemudian divalidasi oleh dua dosen ahli dan diujicobakan secara terbatas kepada 32 mahasiswa PS. Pendidikan Matematika Reguler Sore yang menempuh mata kuliah fisika dasar.

Validasi dilakukan oleh dua orang dosen ahli untuk menilai kelayakan perangkat pembelajaran dikembangkan. Kelayakan perangkat pembelajaran fisika berbasis masalah ini berdasarkan hasil validasi serta sesuai dengan aspek penilaian masing-masing perangkat pembelajaran. Lembar validasi berupa kuisioner tertutup dan terbuka. Kuisioner silabus, RPP terdiri dari 10 butir pernyataan, kuisioner buku ajar fisika dasar terdiri dari 14 butir, kuisioner buku petunjuk praktikum terdiri dari 10 pernyataan, dan kuisioner LKM terdiri dari 12 pernyataan. Berikut adalah hasil validasi secara ringkas yang disajikan dalam Tabel 1.

Tabel 1. Hasil Validasi Silabus, RPP, Buku Ajar Fisika Dasar, Buku Petunjuk Praktikum, LKM, dan Test Hasil Belajar

\begin{tabular}{|c|c|c|c|}
\hline No & $\begin{array}{l}\text { Perangkat } \\
\text { Pembelajaran }\end{array}$ & $\begin{array}{l}\text { Skor } \\
\text { rata- } \\
\text { rata }\end{array}$ & $\begin{array}{l}\text { Kriteria } \\
\text { Skor }\end{array}$ \\
\hline 1 & Silabus & 2,65 & Layak \\
\hline 2 & RPP & 2,68 & Layak \\
\hline 3 & $\begin{array}{l}\text { Buku Ajar } \\
\text { Fisika }\end{array}$ & 3,30 & $\begin{array}{l}\text { Sangat } \\
\text { layak }\end{array}$ \\
\hline 4 & $\begin{array}{l}\text { Buku Petunjuk } \\
\text { Praktikum }\end{array}$ & 3,25 & $\begin{array}{l}\text { Sangat } \\
\text { layak }\end{array}$ \\
\hline 5 & LKM & 2,85 & Layak \\
\hline 6 & Test Hasil Belajar & 3.14 & $\begin{array}{l}\text { Sangat } \\
\text { layak }\end{array}$ \\
\hline
\end{tabular}

Berdasarkan hasil validasi perangkat pembelajaran tersebut, maka perangkat pembelajaran fisika berbasis masalah yang dikembangkan dapat digunakan dalam uji coba terbatas dengan kategori layak digunakan, karena sesuai dengan kriteria kelayakan yaitu nilainya $\geqslant 2,6$. Dari hasil validasi ini maka dapat diketahui kelayakan dari perangkat pembelajaran IPA Terpadu yang dikembangkan untuk mengetahui kelayakan perangkat pembelajaran fisika juga dilakukan uji keterbacaan dan uji coba terbatas.

Setelah dilakukan revisi/perbaikan pada tahap I, kemudian kemudian khusus untuk buku ajar, buku petunjuk praktikum, dan LKM diuji coba tahap II dengan subjek adalah mahasiswa. Tujuannya adalah untuk meminta masukan atau tanggapan dari 6 sampel orang mahasiswa dengan kategori kemampuan tinggi, sedang, dan rendah yang diambil secara acak. Adapun tujuannya adalah untuk mengetahui seberapa tingkat kelayakan pengembangan buku ajar,buku petunjuk praktikum, dan LKM ditinjau dari pengetikan, kelengkapan dan ketepatan kata dan kalimat, penggunaan illustrasi, keterangan gambar/grafik/tabel/diagram, penggunaan ejaan, tanda baca, hurup dan simbol-simbol. 
Hasil lembar validasi keterbacaan buku ajar fisika dasar, buku petunjuk pratikum dan LKM diperoleh skor rata-rata untuk buku ajar fisika dasar sebesar 3,10 dikategorikan sangat layak, buku petunjuk praktikum diperoleh skor rata-rata 3,15 (kategori sangat layak), dan LKM diperoleh skor rata -rata 2,80 (kategori layak).

\section{Tahap Penyebaran (Dessiminate)}

Pada tahap ini secara garis besar intinya adalah melakukan penyempurnaan perangkat pembelajaran dan melakukan uji coba sesunggguhnya di kelas. Perangkat pembelajaran berbasis masalah yang meliputi: silabus, RPP, LKM, petunjuk praktikum, dan buku ajar fisika dasar. Kemudian setelah dilakukan perbaikan dan sedikit revisi diperoleh dan meregistrasi buku ajar fisika dasar layanan yang telah dibuat dilakukan penyempurnaan dalam desain cover dan telah memiliki ISBN No: 978-602-1570-16-6.

Ketika diadakan uji coba terbatas menggunakan perangkat pembelajaran fisika berbasis masalah yang telah dikembangkan, mahasiswa antusias dan bersemangat dalam menggunakan buku ajar, petunjuk praktikum dan LKM tersebut. Materi permasalahan yang dikonfrontasikan ke mahasiswa lebih kontekstual dan masalah yang sedang trend saat ini, sehingga siswa mudah memahami materi perkuliahan yang disampaikan yang disampaikan. Hal ini diperkuat [14] yang menyatakan bahwa ada hubungan kemampuan mengingat, pengetahuan tentang konsep terhadap kemampuan memecahkan masalah. Pentingnya konsep dalam pembelajaran fisika dasar sangat mendukung kemampuan mahasiswa untuk memecahkan persoalan-persoalan fisika fisika dasar.

Untuk hasil nilai uji coba terbatas dapat dilihat pada tabel 2 sebagai berikut:

Tabel 2. Nilai Hasil Uji Coba Terbatas

\begin{tabular}{|c|c|c|c|}
\hline No & Aspek Penilaian & $\begin{array}{l}\text { Rata- } \\
\text { rata }\end{array}$ & Kriteria \\
\hline 1 & $\begin{array}{l}\text { Tingkat } \\
\text { Kelayakan }\end{array}$ & 3,2 & $\begin{array}{l}\text { Sangat } \\
\text { Layak }\end{array}$ \\
\hline 2 & $\begin{array}{l}\text { Nilai Hasil Belajar } \\
\text { Kognitif }\end{array}$ & 76,80 & Baik \\
\hline 3 & Nilai Praktikum & 78,50 & Baik \\
\hline 4 & $\begin{array}{l}\text { Respon } \\
\text { Mahasiswa }\end{array}$ & 85,90 & Sangat Baik \\
\hline
\end{tabular}

Hasil uji coba yang terlihat pada tabel 2 memperlihatkan perangkat yang telah dibuat dari segi kelayakannya sangat sangat layak, karena pada dasarnya melalui perangkat pembelajaran berbasis masalah tersebut diharapkan mahasiswa dapat menyelesaikam masalah - masalah konstektual yang berhubungan dengan materi fiska dasar. Sehingga mahasiswa nantinya lebih mudah dalam memahami suatu konsep secara menyeluruh dan yang lebih penting dapat menyelesaikan permasalahan sehari - hari. Untuk hasil respon mahasiswa dikatakan positif, yaitu mahasiswa merespon secara positif dari implementasi perangkat pembelajaran berbasis masalah (PBM) yang disampaikan, karena persentase kelayakan berdasarkan setiap kriteria mencapai $\geq$ $61 \%$ dan berada dalam interval $81 \%-100 \%$ dengan keterangan sangat merespon perangkat yang telah dikembangkan.

Sedangkan dari hasil nilai hasil belajar kognitif diperoleh nilai rata - rata awal mahasiswa adalah 69,70 , kemudian setelah diberi perlakukan dengan implementasi perangkat pembelajaran diperoleh nilai rata-rata 76,80. Hal ini menunjukan adanya peningkatan dari hasil belajar mahasiswa. Peningkatan ini disebabkan mahasiswa lebih aktif selama pembelajaran berlangsung, karena mahasiswa mencoba menyesuaikan diri dengan model pembelajaran digunakan oleh dosen. Mahasiswa mengikuti proses perkuliahan lebih aktif, terlihat dari aktivitas mahasiswa pada saat kegiatanbelajar, praktikum, menjawab pertanyaan pada LKM dan presentasi. Rata-rata aktivitas mahasiswa terjadi peningkatan, hal ini disebabkan karena mahasiswa mulai terdorong untuk belajar aktif melalui kegiatan yang direncanakan dosen dan lebih siap dalam menerima perkuliahan, terlihat dari banyaknya mahasiswa yang membawa referensi terkait materi yang akan diajarkan, mahasiswa mempersiapkan data untuk kegiatan presentasi kelompok, dan mulai aktif mengajukan pertanyaan. Dosen dalam hal ini hanya sebagai fasilitator dan segala permasalahan, mengidentifikasi masalah, merumuskan masalah , merumuskan hipotesis dikerjakan oleh mahasiswa baik secara mandiri maupun berkelompok. Karena pembelajaran berbasis masalah pada dasarnya mahasiswa diarahkan untuk belajar secara aktif dan berinteraksi dengan teman, guru/dosen dan dunia nyata. Implementasi perangkat pembelajaran dengan berorientasi pada model pembelajaran berbasis masalah telah meningkatkan aktivitas mahasiswa.

Hasil pengamatan sikap ilmiah mahasiswa pada pembelajaran fisika dasar disajikan pada tabel 3 di bawah ini.

Tabel 3. Sikap Ilmiah Mahasiswa pada Mata Kuliah Fisika Dasar

\begin{tabular}{llll}
\hline No & $\begin{array}{l}\text { Indikator Sikap } \\
\text { Ilmah }\end{array}$ & $\begin{array}{l}\text { Rata-rata } \\
\text { Sikap } \\
\text { Ilmiah } \\
(\%)\end{array}$ & $\begin{array}{l}\text { Kategor } \\
\text { i }\end{array}$ \\
\hline 1 & $\begin{array}{l}\text { Rasa Ingin Tahu } \\
\text { (Curiosity) }\end{array}$ & 78,25 & Baik \\
2 & $\begin{array}{l}\text { Respek Terhadap } \\
\text { Bukti dan Fakta }\end{array}$ & 72,20 & Baik \\
\hline 3 & $\begin{array}{l}\text { Kemauan Untuk } \\
\text { Mengubah }\end{array}$ & 75,35 & Baik \\
4 & $\begin{array}{l}\text { Pandangan } \\
\text { Berpikir Kritis }\end{array}$ & 79,85 & Baik
\end{tabular}




\begin{tabular}{llll}
\hline No & $\begin{array}{l}\text { Indikator Sikap } \\
\text { Ilmah }\end{array}$ & $\begin{array}{l}\text { Rata-rata } \\
\text { Sikap } \\
\text { Ilmiah } \\
(\boldsymbol{\%})\end{array}$ & $\begin{array}{l}\text { Kategor } \\
\mathbf{i}\end{array}$ \\
\hline & $\begin{array}{l}\text { (Critical Thinking) } \\
\text { Rata - Rata }\end{array}$ & 76,42 & Baik \\
\hline
\end{tabular}

Dari Tabel 3 dapat diketahui nilai rata-rata persentase sikap ilmiah mahasiswa selama proses pembelajaran fisika dasar adalah $76.42 \%$ (kategori baik), hal ini menunjukkan bahwa proses pembelajaran dengan menggunakan perangkat pembelajaran berbasis masalah telah dapat menumbuhkan sikap ilmiah mahasiswa, dari masing-masing indikator diperoleh nilai rata-rata sikap ilmiah mahasiswa yang tertinggi dan yang terendah. Nilai rata-rata sikap ilmiah mahasiswa yang tertinggi adalah pada indikator berpikir kritis sebesar $79.85 \%$ (kategori baik) sedangkan nilai rata-rata sikap ilmiah mahasiswa yang terendah pada indikator respek terhadap bukti dan fakta sebesar $72.20 \%$ (kategori baik). Kurangnya kemampuan mahasiswa dalam indikator respek terhadap bukti dan fakta disebabkan kurangnya melaporkan data secara secara aktual, walaupun itu bertentangan dengan apa yang diharapkan, kurangnya inisiatif mahasiswa mengecek bagian - bagian fakta/data yang tidak cocok dengan data hasil pengamatan. Sedangkan kemampuan berpikir kritis mengalami peningkatan, hal ini dapat terlihat dari pendapat/ide/gagasan saat perkuliahan fisika dasar mahasiswa sudah berani dan percaya diri dalam menyatakan pendapatnya, namun sebagian mahasiswa yang lain telah mampu mengeluarkan dan menyatakan pendapatnya, mahasiswa mencari informasi tambahan terkait materi yang diajarkan, serta melengkapi data hasil pengamatan pada pengukuran mekanik dan menentukan laju aliran kalor pada logam. Berdasarkan hasil observasi sebagian mahasiswa mencari referensi tambahan dari internet dan sumber lainnya untuk melengkapi data hasil pengamatan dan untuk mencari informasi tambahan tentang materi yang diajarkan, melalui berpikir kritis mahasiswa dituntut untuk memiliki kemampuan menganalisis yang tinggi terkait materi yang diajarkan, sehingga dapat melatih kemampuan dan kreativitas mahasiswa. Mahasiswa yang mempunyai sikap ilmiah yang tinggi akan memiliki kelancaran dalam berpikir sehingga akan termotivasi untuk berprestasi dalam belajar dan memiliki komitmen yang kuat untuk mencapai keberhasilan dan keunggulan dalam perkuliahan. Pada indikator rasa ingin tahu dengan rata-rata persentase sebesar 78.25\% (kategori baik), sebagian besar mahasiswa terlihat antusias dalam mencari jawaban dari pertanyaan yang diberikan dosen dan membaca referensi terkait materi yang diajarkan melalui internet dan sumber bacaan lainnya, dilengkapi dengan sarana laptop hamper semua mahasiswa mencari referensi lewat blog di internet . Keingintahuan mahasiswa yang tinggi dalam perkuliahan fisika dasar dapat diketahui dari usaha yang dilakukan mahasiswa tersebut dalam memahami suatu permasalahan yang diberikan dan mengghubungkan dengan konsep-konsep fisika yang baru . Hal ini diperkuat dengan penelitian yang dilakukan oleh [5] dan [3] yang menyatakan bahwa siswa yang belajar dengan model pembelajaran berbasis masalah mempunyai sikap ilmiah dan keterampilan berpikir lebih baik daripada siswa yang belajar dengan model konvensional dan model ekspositori. Pada dasarnya Pembelajaran berbasis masalah dapat membangkitkan minat siswa, nyata, dan sesuai untuk membangun kemampuan intelektual. Seperti hasil penelitian yang dilakukan oleh [15] menyatakan bahwa pembelajaran berbasis masalah dapat meningkatkan kemampuan berpikir dan motivasi belajar.

\section{PenutuP}

Berdasarkan hasil pengembangan perangkat dan hasil uji coba maka dapat disimpulkan berikut : 1) Kelayakan perangkat pembelajaran fisika berbasis masalah yang dikembangkan yaitu berdasarkan validasi yang dilakukan pada silabus, RPP, buku ajar fisika dasar, buku petunjuk praktikum, LKM dan tes hasil belajar yang dikembangkan diperoleh: silabus layak digunakan dan mendapat skor rata-rata 2,65 dengan kriteria layak. RPP berorientasi pembelajaran berbasis masalah layak digunakan dan mendapat skor rata-rata 2,68 dengan kiteria layak. Buku ajar fisika dasar layak digunakan dengan sedikit revisi dari desain cover dan mendapat skor rata-rata sebesar 3,30 dengan kriteria sangat layak. Buku petunjuk praktikum fisika dasar layak digunakan dan mendapatkan skor rata -rata 3,25 dengan kriteria sangat layak. LKM layak digunakan dan mendapat skor rata-rata 2,85 dengan kriteria layak dan tes hasil belajar fisika layak digunakan dengan sedikit revisi dan mendapat skor rata-rata sebesar 3,14 dengan kriteria sangat layak. 2) Berdasarkan analisis hasil belajar pada aspek kognitif, nilai praktikum, dan sikap ilmiah mahasiswa, bahwa perangkat pembelajaran berbasis masalah yang dikembangkan dapat digunakan untuk hasil belajar dan sikap ilmiah mahasiswa. Hal ini terjadi karena pembelajaran berpusat pada mahasiswa dan respon mahasiswa positif. 3) Mahasiswa memberikan respon positif terhadap perangkat pembelajaran berbasis masalah yang telah dikembangkan dengan persentase respon sebesar $85,90 \%$.

Berdasarkan hasil penelitian dalam rangka meningkatkan kualitas perkuliahan , maka disarankan untuk meningkatkan hasil belajar dan sikap ilmiah mahasiswa agar dosen memberikan permasalahan permasalahan yang dapat menggugah rasa ingin tahu dan permasalahan bersifat nyata dan mengikuti trend 
kejadian atau peristiwa pada saat berlangsungnya perkuliahan.

\section{UCAPAN TERIMA KASIH}

Penulis mengucapkan terima kasih dalam penelitian maupun publikasi ilmiah, termasuk donatur penelitian kepada Universitas Mataram yang membantu penelitian ini lewat dana DIPA Universitas Mataram Tahun Anggaran 2014.

\section{REFERENSI}

[1] Munthe, Bermawi, 2009. Desain Pembelajaran. Yogyakarta:Penerbit Pustaka Insan Madani.

[2] Sanjaya, Wina. 2010. Kurikulum dan Pembelajaran: Teori dan Praktik Pengembangan Kurikulum Tingkat Satuan Pendidikan (KTSP). Cetakan ketiga.Jakarta: Penerbit Kencana

[3] Astika, Urip. I.Kd , Suma, \& Suastra. 2013. Pengaruh Model Pembelajaran Berbasis Masalah Terhadap Sikap Ilmiah dan Ketrampilan Berpikir Kritis. Jurnal Pasca Sarjana Universitas Pendidikan Ganesha (online). http://pasca.undiksha.ac.id/ejournal/index.php/jurnal ipa/download. Diakses 5 September 2014.

[4] Fahruddin, Jufri, A.W, \& Jamaluddin. 2014. Pengaruh Model Pembelajaran Kooperatif terhadap Sikap Ilmiah Ditinjau dari Kemampuan Akademik Mahasiswa. Prosiding Seminar Nasional Sains dan Inovasi Pembelajaran Berbasis Kearifan Lokal. 22 November 2014. Mataram. Hal.1-4

[5] Gunada, I. W. 2010. Efektivitas Model Pembelajaran Berbasis Masalah dalam Meningkatkan Sikap Ilmiah dan Keterampilan Berpikir Kritis Siswa SMA (Studi Eksperimen dalam Pembelajaran Fisika di Kelas X SMA). Prosiding Seminar Nasional Peningkatan Kualitas Pembelajaran MIPA Melalui Pelaksanaan Lesson Study, Penelitian, dan Inovasi Pembelajaran. 3 Juli 2010, Mataram. Hal. 130 -138.

[6] Ommundsen, P. 2001. Problem Based Learning in Biologi With 20 Case Examples (Online), (http://www. saltspring.com/capewest/pbl.htm, diakses 5 September 2014.

[7] Amir, Taufiq, 2009. Inovasi Pendidikan Melalui Problem Based Learning. Jakarta: Kencana Prenada Media Group.

[8] Trianto. 2011. Medesain Model Pembelajaran Inovatif Progresif. Jakarta: Kencana Prenada Media Group.
[9] Santyasa, 2009. Metode Penelitian Pengembangan dan Teori Pengembangan Modul. Makalah. Disajikan dalam Pelatihan Bagi Para Guru TK,SD, SMP, SMA, dan SMK di Kecamatan Nusa Penida. 12-14 Januari 2009.

[10] Warsono dan Hariyanto. 2012. Pembelajaran Aktif Teori dan Asesmen. Bandung: PT Remaja Rosdakarya.

[11] Slameto. 2003. Belajar dan Faktor-Faktor yang Mempengaruhinya. Jakarta: Rineka Cipta.

[12] Purwanto. 2011. Evaluasi Hasil Belajar. Yogyakarta: Pustaka Pelajar.

[13] Thiagarajan, Semmel \& Semmel, 1974. Instructional Development for Trainning Teachers of Exceptional Children. Indiana: Indiana University.

[14] Subroto. 2011. Kontribusi Kemampuan Mahasiswa Mengingat Konsep, Miskonsepsi dan Menggunakan Prinsip Terhadap Kemampuan Menjelaskan dalam Memecahkan Masalah. Prosiding Seminar Nasional Penelitian, Pendidikan dan Penerapan MIPA, 14 Mei Universitas Negeri Yogyakarta

[15] Susilo, A. B., Wiyanto dan Supartono. 2012. Model Pembelajaran IPA Berbasis Masalah untuk Meningkatkan Motivasi Belajar dan Keterampilan Berpikir Kritis Siswa SMP. Unnes Science Education Journal (1): 12-20.

\section{Biografi Penulis}

I Wayan Gunada, pria kelahiran Tabanan, 15 Agustus 1975 dan merupakan salah satu staf tenaga pengajar di Program Studi Pendidikan Fisika FKIP Universitas Mataram. Pendidikan formal diperoleh antara lain : (S1) Sarjana Fisika Universitas Udayana Denpasar tahun 2000, Magister Penelitian dan Evaluasi Pendidikan (PEP) Univ. Pendidikan Ganesha Singaraja tahun 2010. Pelatihan yang pernah di ikuti diantara: Workshop Pengembangan Media Pembelajaran Berbasis ICT tahun 2012 di Mataram. Workshop Nasional Pengembangan Metode dan Perangkat Pembelajaran Berdasar Standar Nasional Pendidikan Tinggi tahun 2014 di Mataram .Karya ilmiah dalam bentuk buku : Reveiw Curriculum \& Content Analysis of Physics II (2012), Kajian Fisika SMA (2013), Exsperiment Physics (2014), Fisika Dasar (2014). Menulis artikel ilmiah: Pengaruh Model Pembelajaran Fisika Berbasis Masalah untuk Meningkatkan Hasil Belajar Ditinjau dari Gaya Kognitif Mahasiswa (2013)

Kegiatan ilmiah : sebagai pemakalah pada kegiatan seminar nasional Arah Pendidikan MIPA Masa Depan: Antara Harapan dan Kenyataan (2013), 
sebagai pemakalah pada Seminar Nasional Sains dan Inovasi Pembelajaran Berbasis Kearifan Lokal IKIP Mataram (2014). Sebagai Juri Kegiatan Kompetisi Internasional Siswa Berbakat Regional Indonesia Tengah (Indonesia Math and Science Camp 2014).

Hj. Hairunnisyah Sahidu, lahir di Raba Bima, 24 September 1957. Pendidikan formal diperoleh antara lain : Gelar sarjana muda dan sarjana diperoleh pada jurusan Fisika IKIP Negeri Yogyakarta tahun 1979 (Dra), pendidikan (S2) Magister Manajemen Pendidikan (M.Pd) diperoleh di Universitas Negeri Surabaya tahun 1984. Pelatihan/Kegiatan Ilmiah yang pernah diikuti : penataran tenaga akademik, metodologi penelitian, AMDAL, TPB bidang Fisika (ITB), persiapan perkuliahan lanjut Mekanika (ITB), Mekanika Kuantum (Udayana), Gelombang dan Optik (UGM), pelatihan peningkatan asesmen berbasis kompetensi, Lesson Study (Yogyakarta), National Training of Trainer Lesson Study (Malang), dan Workshop Nasional Pengembangan Metode dan Perangkat Pembelajaran Berdasar Standar Nasional
Pendidikan Tinggi tahun 2014 di Mataram. Karya Ilmiah: Buku Ajar Penilaian Hasil Belajar (2013)

Sutrio, kelahiran Kediri 10 Januari 1967. Pendidikan formal : S1 Pendidikan Fisika IKIP Malang tahun 1990, (S2) Fisika (M.Si) diperoleh di ITB Bandung tahun 1997. Riwayat Pekerjaan: Konsultan SEQIP (2005), Tim Pakar IPA Dinas Dikpora Propinsi NTB (2006-2008), Dosen PS. Pend. Fisika FKIP Unram (1996-sekarang) .

Mata kuliah yang diampu : Fisika Dasar, Fisika Eksperimen I dan II, Listrik Magnet, dan Pendahuluan Fisika Zat Padat.

Kegiatan ilmiah : melakukan penelitian dengan judul Pengembangan Model Pembelajaran Fisika Berbasis Multimedia Interaktif Berorientasi pada Keterampilan Berfikir Kritis Peserta Didik (2012) sebagai pemakalah pada Seminar Nasional Sains dan Inovasi Pembelajaran Berbasis Kearifan Lokal IKIP Mataram (2014). Sebagai Juri Kegiatan Kompetisi Internasional Siswa Berbakat Regional Indonesia Tengah (Indonesia Math and Science Camp) tahun 2014. 